\title{
PEMBELAJARAN AL-QUR'AN HADIS BERBASIS KONTEKSTUAL DI MTS. PENDIDIKAN AGAMA ISLAM MEDAN
}

\section{(Studi Kasus pada Pembelajaran Daring)}

\author{
Latifah Hanum \\ Universitas Islam Sumatera utara \\ E-mail: latifah.hanum@fkip.uisu.ac.id
}

How to Cite:

Hanum. L. (2021). Pembelajaran Al-Qur'an Hadis Berbasis Kontekstual di MTs. Pendidikan Agama Islam Medan (Studi Kasus pada Pembelajaran Daring). Fitrab: Journal of Islamic Education, 2(1), 66-79.

\begin{abstract}
ARTICLE HISTORY
Received : 09 September 2021

Revised : 18 September 2021

Accepted : 19 September 2021

Published : 20 September 2021
\end{abstract}

\section{KEYWORDS:}

Al-Qur'an Hadith, Contextual Learning, Online Learning

\section{KATA KUNCI:}

Al-Qur'an Hadis, Pembelajaran Kontekstual, Pembelajaran Daring

\section{ABSTRACT}

This study aims to analyze contextual-based learning of the Qur'an Hadith during the online learning period. This research uses qualitative research methods, based on case studies. This research was conducted at MTS. Islamic Religious Education with research informants are principals, teachers, and students. Methods of data collection using interview techniques, observation, and documentation. The data obtained were then analyzed using data reduction techniques, data display, and drawing conclusions. The findings of this study indicate that contextual-based online learning planning for Al-Qur'an Hadith is carried out with the stages of determining core competencies and basic competencies to then formulate learning objectives and indicators, determine materials and connect materials with the practice of worship in students' daily lives, determine methods and formulations learning evaluation. The implementation of learning is carried out online and accompanied by parents. After teaching the material, the teacher asks students to make certain worship habits based on the verses and hadiths that have been taught. Evaluation is done authentically, and uses observation techniques on the basis of a predetermined scale.

\section{RIWAYAT ARTIKEL}

Diterima :09 September 2021

Direvisi : :18 September 2021

Disetujui : 19 September 2021

Diterbitkan :20 Septermber 2021

\section{ABSTRAK}

Penelitian ini bertujuan untuk menganalisis pembelajaran Al-Qur'an Hadis berbasis kontekstual selama masa pembelajaran daring. Penelitian ini menggunakan metode penelitian kualitatif, berbasis studi kasus. Penelitian ini dilaksanakan di MTS. Pendidikan Agama Islam dengan informan penelitiannya adalah kepala sekolah, guru, dan siswa. Metode pengumpulan data dengan wawancara, observasi, dan dokumentasi. Analasis data melalui reduksi data, penampilan data, dan penarikan simpulan. Temuan penelitian ini menunjukkan bahwa perencanaan pembelajaran Al-Qur'an Hadis berbasis kontekstual secara daring dilakukan dengan tahapan menentukan kompetensi inti dan kompetensi dasar untuk kemudian merumuskan tujuan dan indikator pembelajaran, menentukan materi dan menghubungkan materi dengan pengamalan ibadah dalam keseharian siswa, penentuan metode dan perumusan evaluasi pembelajaran. Pelaksanaan pembelajaran dilakukan secara daring dan didampingi oleh orang tua. Setelah mengajarkan materi, maka guru meminta siswa untuk melakukan pembiasaan ibadah tertentu yang dasarnya ayat dan hadis yang telah diajarkan. Evaluasi dilakukan secara autentik, dan menggunakan teknik observasi dengan dasar skala yang telah ditetapkan. 
PENDAHULUAN

Pembelajaran Al-Quran Hadis menjadi pembelajaran wajib pada semua jenjang di madrasah baik pada tingkat dasar maupun menengah. Hal ini sebagaimana yang tertuang pada struktur kurikulum K-13 untuk satuan pendidikan madrasah. Pembelajaran Al-Qur'an Hadis pada dasarnya dua konten pelajaran yang berbeda, namun secara nomenklatur pembelajaran Al-Qur'an Hadis menjadi satu nama pembelajaran, yakni Al-Qur'an Hadis. Pada satuan pendidikan sekolah tidak dikenal nomenklatur pembelajaran Al-Qur'an Hadis, yang ada hanyalah pembelajaran Pendidikan Agama Islam, namun bukan berarti siswa pada satuan pendidikan sekolah tidak mempelajari Al-Qur'an Hadis, mereka tetap mempelajarinya hanya saja cakupannya lebih sempit dibandingkan dengan siswa yang berada pada madrasah. (Nasution, 2019).

\section{Pembelajaran Al-Qur'an Hadis} memiliki penekanan pada ayat-ayat tertentu, dan hadis yang tertentu pula untuk di pelajari baik secara bacaan, pemaknaan, dan pengamalan. Ayat-ayat dan hadis tersebut tentu yang memiliki urgensi bagi perkembangan diri siswa, terutama sebagai acuan dalam pembentukan perilaku keseharian yang sesuai dengan tuntunan AlQur'an Hadis. Atas dasar itu tak heran jika materi pelajaran Al-Qur'an Hadis berisikan ragam ayat dan hadis pilihan dengan penekanan pada membacanya, memaknainya, dan mengamalkannya dalam kehidupan sehari-hari. (Muthmainnah \& Herawati, 2021).

Atas dasar karekteristik itu maka pembelajaran Al-Qur'an Hadis dapat diklasifikasikan menjadi dua bentuk pembelajaran, yaitu pembelajaran secara teksual dan pembelajaran kontekstual. Pembelajaran secara tekstual maksudnya pembelajaran yang penekanannya pada aspek teoritis, dalam arti pembelajaran yang penekanannya pada membaca dan memaknai teks Al-Qur'an Hadis.(Juliana, 2014). Sedangkan pembelajaran secara kontekstual maksudnya pembelajaran yang penekanannya pada pengaitan antara materi yang diajarkanya dengan situasi dunia nyata siswa dan mendorong siswa membuat hubungan antara pengetahuan yang dimilikinya dengan penerapan dalam kehidupan sehari-hari. Dua bentuk pembelajaran ini sebenarnya bukanlah sesuatu yang terpisah melainkan satu kesatuan. Pembelajaran Al-Qur'an Hadis secara tekstual saja tanpa kontekstual akan membuat perkembangan siswa tidak tercapai sebagaimana yang diharapkan, dalam arti ada ketidaksempurnaan pemahaman. (R. R. Lubis et al., 2019).

\section{Model pembelajaran kontekstual} merupakan model yang dikembangkan dari teori konstruktivisme, yang dikembangkan oleh Piaget dan Vygotsky teori ini memandang bahwa peningkatan pengetahuan merupakan hasil konstruksi pembelajaran 
dari pemelajar, bukan sesuatu yang “disuapkan" dari orang lain. Teori ini memandang bahwa pemahaman itu terbangun dari pemahaman yang dimiliki dengan kontak nyata dengan penerapan yang dilakukan dalam sehari-hari. Artinya akan berbeda pemahaman siswa yang hanya mempelajari secara tekstual semata dengan siswa yang mempelajarinya dengan melibatkan atau mengaitkannya dalam kehidupan sehari-hari. Pembelajaran kontekstual sangat relevan dengan tuntutan perkembangan zaman saat ini, sebagaimana tuntutan pada kurikulum 2013 bahwa siswa tidak hanya dituntut untuk mengetaui akan tetapi mampu untuk mengkomunikasikannya pada orang lain, sebagaimana yang termaktub dalam istilah pendekatan saintifik.(R. R. Lubis et al., 2020).

Pembelajaran Al-Qur'an Hadis sangat identik dengan teks, sehingga pembelajaran yang ada pun kerap dilakukan bagaimana agar siswa mampu untuk membaca teks $\mathrm{Al}$ Qur'an Hadis tersebut dan memahami makna dari kandunganya. Pembelajaran seperti ini memang sudah berlangsung sangat lama, bahkan tak salah jika dikatakan model yang seperti itu dikategorikan sebagai model pembelajaran klasik yang sarat akan teacher centred. Saat ini arah pembelajaran mengalami tuntutan perubahan dari teacher centred kepada student centred. Dalam hal ini pembelajaran AlQur'an Hadis berbasis kontekstual termasuk pada student centred. (Al-Balushi et al., 2020).
Walaupun dikatakan bahwa saat ini tuntutan zaman sudah berubah, namun fenomena yang terjadi saat ini pembelajaran Al-Qur'an Hadis cenderung didominasi dengan pembelajaran tekstual. Seperti belajar membaca, menulis, menghafal, dan memahami terjemahannya. Hal yang demikian sebenarnya tidaklah salah, namun yang menjadi persoalan bahwa dengan alasan tekstual tersebut, guru kerap melupakan pembelajaran Al-Qur'an Hadis secara kontekstual. Kondisi seperti ini dialami di MTS. Pendidikan Agama Islam, berdasarkan wawancara awal yang penulis lakukan kepada guru mata pelajaran Al-Qur'an Hadis, pada mulanya pembelajaran Al-Qur'an Hadis yang diterapkan di madrasah ini selalu berbasis tekstual, siwa diminta untuk membaca AlQur'an Hadis baik secara individual maupun klasikal, kemudian di tulis, lalu kemudian di nilai oleh sang guru. Hampir selalu begitu untuk setiap harinya, sehingga pengamalan siswa tentang ayat dan hadis menjadi rendah. Namun saat ini tidaklah demikian pembelajaran Al-Qur'an Hadis kini dikemas menjadi ragam aktivitas ataupun tradisi yang memungkinkan siswa untuk memiliki pemahaman yang tidak hanya sebatas pada tataran kognitif semata, akan tetapi juga terampil dalam mengamalkan ayat dan hadis tersebut dalam kehidupan sehari-hari.

$$
\text { Selain untuk memberikan }
$$

pemahaman yang kompleks, pembelajaran secara kontekstual juga akan menghantarkan 
siswa menjadi muslim yang terampil mengamalkan apa yang terdapat dalam ayat maupun hadis Nabi Saw. Karena terhadap ayat Al-Qur'an maupun hadis seyogianyalah seorang muslim itu tidak hanya membacanya tetapi juga mengamalkannya dalam kehidupan sehari-hari. Dalam hal ini kerap kali siswa tidak memahami yang terdapat dalam kandungan ayat, oleh karena itulah perlu kiranya untuk mengaitkan pembelajaran yang berkaitan dengan ayat dan Hadis dengan pengamalan dalam keseharian siswa. (Zakariah et al., 2017).

Penelitian ini terbilang memiliki kebaharuan, hal ini tampak dari beberapa penelitian yang memiliki relevansi akan tetapi penelitian ini memiliki kekhususan. Seperti penelitian tentang peningkatan prestasi belajar melalui pembelajaran Al-Qur'an berbasis kontekstual (Muhayanti \& Yulia, 2020), asas-asas pembelajaran Kontekstual (Wirdati \& Sulaiman, 2018), pendidikan karakter melalui pembelajaran PAI berbasis Kontekstual (Budianto, 2010), pengelolaan pembelajaran konstekstual (Nafia, 2017), aplikasi pendekatan model kontekstual dalam pembelajaran PAI (Zaman, 2020), moderasi Islam dalam pembelajaran Al-Qur'an (Winata et al., 2020), Peningkatan mutu pendidkan Islam melalui pembelajaran kontekstual (Kusen, 2017), pengaruh pembelajaran kontekstual terhadap kinerha guru (Safitri, 2016), rekonstruksi pembelajaran pendidikan agama Islam (Ni'mah, 2017), peningkatan motivasi dan minat belajar melalui pemodelan pembelajaran kontekstual (Syahdan, 2019). Berdsarkan hasil penelitian relevan tersebut tampak masih terdapat ruang kosong fokus penelitian yakni pembelajaran Al-Qur'an Hadis berbasis kontekstual secara daring, tentu hal kebaruan yang dapat berkontribusi untuk tetap mengoptimalkan capaian pembelajaran Al-Qur'an Hadis di masa pandemi Covid-19 saat ini.

Penerapan pembelajaran kontekstual di masa pandemi Covid-19 memang mengalami kendala, sebab pembelajaran tidak dilakukan secara tatap muka melainkan dilakukan secara daring, tentu dengan model pembelajaran seperti itu menyulitkan siswa untuk dapat mengawasi secara langsung tahapan demi tahapan perkembangan peserta didik, terutama dalam mengaitkan pembelajaran tersebut dalam kehidupan sehari-hari. Tentu menjadi sangat menarik jika penerapan pembelajaran Al-Qur'an Hadis berbasis konstekstual yang dilaksanakan secara daring diangkat menjadi topik penelitian. (M. Lubis et al., 2020).

Secara umum penelitian ini bertujuan untuk menganalisis pembelajaran Al-Qur'an Hadis berbasis kontekstual yang dilaksanakan di masa pandemi Covid-19. Namun secara khusus tujuan penelitian ini ialah untuk mengetaui (1) perencanaan pembelajaran AlQur'an Hadis berbasis kontekstual secara daring, (2) pelaksanaan pembelajaran AlQur'an Hadis berbasis kontekstual secara 
daring, (3) evaluasi pembelajaran Al-Qur'an Hadis berbasis kontekstual secara daring, (3) evaluasi .

Tentunya penelitian ini diharapkan memiliki kontribusi bagi perkembangan pembelajaran Al-Qur'an Hadis di masa-masa mendatang. Namun secara khusus tentunya berkontribusi kepada guru dalam meningkatkan tujuan pembelajarannya, sehingga peserta didik tidak hanya mampu secara kognitif akan tetapi mampu secara komprehensif, baik kognitif, afektif, psikomotorik dan pengamalannya dalam kehidupan sehari-hari.

\section{KAJIAN TEORI}

Pembelajaran tidak sama dengan pengajaran, pembelajaran lebih cenderung pada proses membelajarkan peserta didik, dengan cara menjalin interaksi belajar dengan guru, sumber belajar, peserta didik lain dan lingkungan. Sedangkan pengajaran lebih cenderung proses menyampaikan materi pelajaran dari guru kepada muridnya. Pembelajaran bersifat interaktif dan aktif, sementara pengajaran bersifat pasif, dimana siswa menjadi objek yang hanya sekedar menerima apa yang disampaikan oleh peserta gurunya.

Kontekstual artinya berkaitan dengan konteks, atau sesuai dengan kehidupan nyata yang dialami oleh siswa. Jika dikaitkan dengan pembelajaran maka pembelajaran kontekstual artinya pembelajaran yang tidak hanya berbasis pada tekstual, akan tetapi mengarahkan peserta didik untuk terlibat aktif dalam kegiatan menerapkan pembelajaran yang telah dia terima. Pembelajaran kontekstual saat ini menjadi yang sangat banyak diminati sebab ia memiliki beberapa keunggulan, di antaranya: (1) membuat siswa menjadi Aktif, (2) siswa lebih matang dalam memahami materi pelajaran, (3) terjalinnya interaksi antar satu peserta didik dengan peserta didik lainnya, (4) menghemdaki guru menjadi lebih kreatif untuk mengemas dan mengarahkan pembelajaran. Namun di samping itu pembelajaran kontekstual juga memiliki kekurangan, di antaranya: (1) membutuhkan perencanaan yang matang, (2) siswa lebih banyak beraktivitas di luar, (3) interaksi di kelas membuat suasana menjadi tidak kondusif, (4) melibatkan ragam aktivitas yang bersamaan. (Abrianto et al., 2018).

Teori belajar yang mendasari pembelajaran kontekstual ialah teori belajar kontruktivisme yang dikembangkan oleh Piage dan Vigotsky. Teori ini mengemukakan bahwa seseorang belajar atau mendapatkan pengetahuan dari hasil mengkonstruk informasi-informasi yang ia peroleh. Informasi-informasi yang ada selama ini akan terkonstruk dengan informasi-informasi baru yang diterima oleh siswa. Dengan kata lain, seperti aktivtas membangun sebuah bangunan, yang setiap saat mengalami pertambahan dari satu tahapan ke tahapan 
lain. Keberhasilan belajar dalam teori konstruktivisme, terbukti dari semakin bertambahnya pemahaman siswa dari satu hari ke hari yang lain. Teori belajar konstruktivisme juga menyakini bahwa apa yang telah didapat secara pengajaran (transfer knowledge) terkadang tidak serta merta komprehensif dipahami siswa, lazimnya siswa akan lebih memahami sesuatu hal ketika ia merasakan sendiri pengalaman dari pengetahuan yang ia dapat itu. Maka pembelajaran konstekstual menyediakan kondisi tersebut agar siswa dapat mengkonstruksi pemikirannya melalui pengalaman yang nyata. (Waseso, 2018).

Pembelajaran kontekstual pada dasarnya dapat diterapkan pada pelajaran apa saja, termasuk dalam hal ini pelajaran AlQur'an Hadis. Justru pembelajaran ini sangat menghendaki konstekstualitas, sebab ciri khas dari pembelajaran ini adalah tekstualitas. Jika hanya tekstualitas saja yang diajarkan tentulah akan membuat siswa mengalami, kekurangan dalam memahami materi pelajaran tersebut. Ditambah lagi pada situasi pandemic Covid-19 dimana siswa sangat membutuhkan pengalaman langsung, sebab jarak yang jauh sangat tidak memungkinkan untuk mempelajarinya hanya dengan tekstualitas semata.

\section{METODE PENELITIAN}

Penelitian ini menggunakan jenis penelitian kualitatif dengan model field research. Pendekatan yang digunakan dalam penelitian ini ialah studi kasus. Pemilihan ini karena beranjak dari kasus yang dialami di MTS. Pendidikan agama Islam selama mengalami pembelajaran berbasis daring. Kasus tersebut khususnya saat terjadi kendala yang dialami oleh guru dalam penerapan pembelajaran Al-Qur'an Hadis berbasis kontekstual.

Penelitian ini dilakukan selama tiga bulan yakni dari bulan juni sampai dengan Agustus 2021. Penelitian ini dilaksanakan di MTS. Pendidikan Agama Islam yang beralamat di Jalan Pendidikan Gg. Tertib No. 8 Medan, Kecamatan Medan Timur. Peneltiian ini dilaksanakan dengan serangkaian kegiatan yang dimulai dari tahap perencanaan penelitian, pelaksanaan penelitian, dan penulisan laporan penelitian.

Adapun informan dalam penelitian ini ialah guru mata pelajaran Al-Qur'an Hadis, Kepala sekolah, dan siswa. Pada guru mata pelajaran ditelusuri informasi berupa perencanaan, pelaksanaan, dan evaluasi pembelajaran Al-Quran Hadis berbasis kontekstual yang dilakukan selama pembelajaran daring. Dari kepala sekolah ditelusuri data yang berkaitan dengan ragam kebijakan kepala sekolah terkait dengan model pembelajaran daring yang dilaksanakan selama masa pandemic Covid19, terutama pada kebijakan pada pembelajaran yang berkenaan dengan kontekstual. Dari siswa diperoleh data yang 
berkaitan dengan respon yang muncul setelah melaksanakan pembelajaran Al-Qur'an Hadis berbasis kontekstual selama daring.

Pengumpualan data dilakukan melalui tida teknik yakni wawancara, observasi, dan dokumentasi. Wawancara dilakukan untuk menggali informasi secara lisan baik dari guru, kepala sekolah, dan siswa terkait dengan perencanaan, pelaksanaan, dan evaluasi pembelajaran berbasis konstekstual secara daring. Observasi bertujuan untuk mendukung temuan penelitian yang dilakukan secara wawancara, bahkan observasi dijadikan sebagai teknik untuk mengamati secara langsung apa yang dilakukan siswa. Dalam penelitian ini, peneliti meminta izin kepada guru mata pelajaran untuk mengamati secara langsung proses pembelajaran daring yang dilakukan oleh guru dengan cara ikut serta dalam group pembelajaran yang memang ada untuk setiap mata pelajaran. Namun dalam kondisi ini peneliti hanya berfungsi sebagai seorang peneliti tidak dalam hal yang lain. Kemudian teknik dokumentasi dilakukan untuk menganalisis dokumen-dokumen yang berkaitan dengan pelaksanaan pembelajaran Al-Qur'an Hadis seperti dokumen rencana pelaksanaan pembelajaran, silabus, hasil evaluasi, dan juga dokumentasi pelaksaaan pembelajaran yang telah dilaksanakan selama ini.

Analisis data dalam penelitian ini meggunakan model Miles dan Huberman, yang terdiri dari beberapa tahapan, yakni pengumpulan data, reduksi data, penampilan data, dan penarikan simpulan. Untuk menjaga keabsahan data yang diperoleh maka uji keabshanan data dilakukan melalui trianggulasi data, dan member crosscheck. Untuk lebih detailnya rancangan penelitian ini di uraikan dalam bentuk skema penelitian:

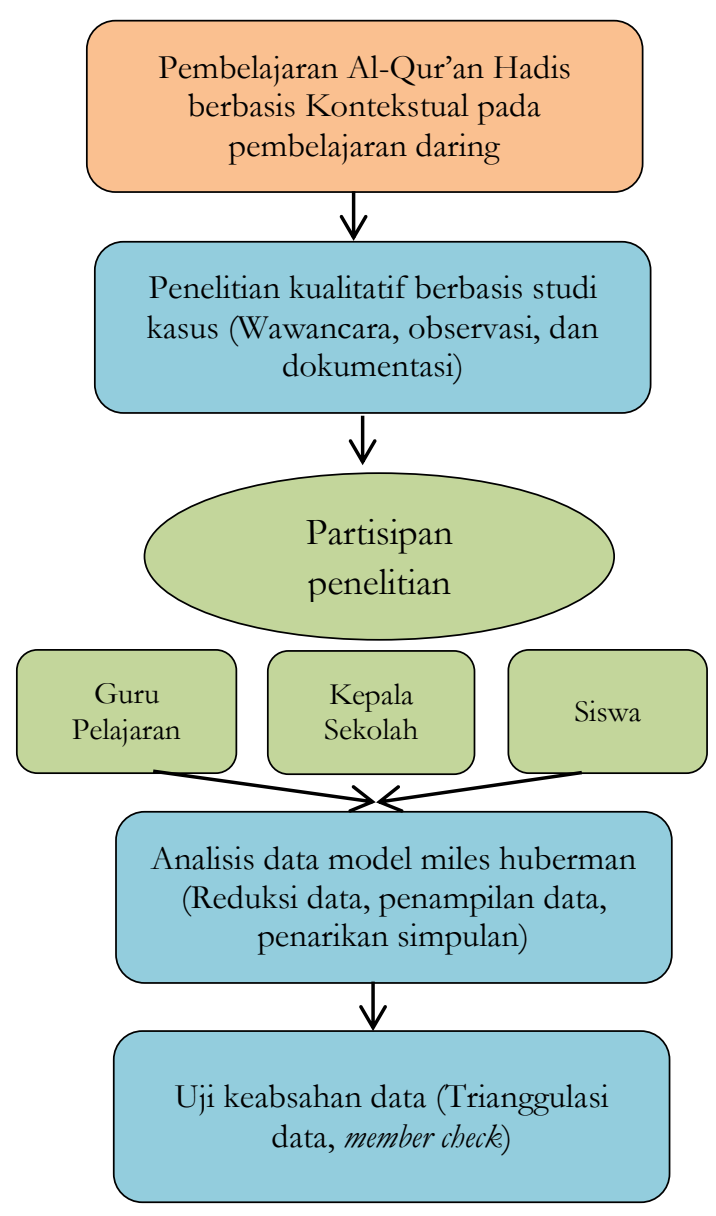

Bagan 1. Alur Penelitian

\section{HASIL DAN PEMBAHASAN PENELITIAN}

Sebagaimana yang telah dikemukakan sebelumnya bahwa penelitian ini akan membahas pada tiga hal yakni perencanaan, Pelaksanaan pembelajaran dan evaluasi pembelajaran Al-Qur'an hadis berbasis kontekstual berbasis daring. Penjelasan 
tersebut akan diuraikan berikut ini:

\section{Perencanaan pembelajaran Al-Qur'an} Hadis berbasis kontekstual secara daring

Perencanaan pembelajaran pada dasarnya bukanlah sekedar membuat RPP ataupun silabus pembelajaran semata, akant tetapi merencanakan pembelajaran yang tepat untuk digunakan. Perencanaan meliputi menentukan tujuan dan indikator pembelajaran, merumuskan metode dan media pembelajaran, serta menentukan langkah demi langkah pembelajaran tersebut.

Pembelajaran Al-Qur'an Hadis secara kontekstual memerlukan rumusan keterkaitan antara materi yang diajarkan dengan kegiatan yang dialami siswa dalam keseharian. Maka berdasarkan hasil observasi yang peneliti lakukan terlihat bahwa guru merencanakan materi pembelajaran yang akan diajarkan, dan menghubungkan materi tersebut dengan aktivitas pengamalan terhadap materi ayat atau hadis tersebut. Misalnya saja yang berhasil penulis amati adalah ketika guru merumuskan tujuan pembelajaran surah AlKafirun (bacaan, terjemahan, dan kandungan ayatnya), guru tidak hanya mengajarkan pada siswa tentang cara membaca dan hokum tajwidnya semata, dan tidak pula sekedar menjelaskan terjemahan dan makna kandungannya. Akan tetapi guru meminta siswa untuk membaca Surah Al-Kafirun tersebut menjadi salah satu ayat dalam bacaan shalatnya, dan dikarenakan dalam situasi pembelajaran daring, maka guru meminta siswa untuk mengirimkan bukti rekaman video shalat yang di dalamnya membaca surah Al-Kafirun.

Selain persiapan materi pelajaran, guru juga mempersiapkan silabus dan rencana pelaksanaan pembelajaran. Berdasarkan wawancara yang penulis lakukan pada informan, yakni guru pelajaran mereka menjelaskan bahwa di dalam Rencana pelaksanaan pembelajaran tertuang tentang pembelajaran kontekstual, dalam hal ini berbentuk kegiatan yang melibatkan pengamalan siswa dalam kehidupan seharihari. Bahkan pada bagian kolom strategi pembelajaran terdapat keterangan jelas tentang strategi pembelajaran yang digunakan yakni Active learning dan contextual teaching learning. Namun sayangnya tidak dijelaskan bagaimana langkah tahap demi tahap dari pelaksanaan strategi pembelajaran tersebut. (Sista, 2017).

Hasil wawancara juga menunjukkan bahwa dalam perencanaan pembelajaran guru selalu memformulasikan terlebih dahulu, materi apa yang tepat digunakan dalam pembelajaran yang dapat diarahkan pada kontekstual. Bahkan berdasarkan kondisi mewabahnya Covid-19 saat ini pembelajaran secara konstekstual memang menjadi prioritas sebab sangat tidak memungkinkan untuk melakukan pembelajaran berbasis diskusi, kooperatif, dan sejenisnya. Jika pun memungkinkan mungkin akan mengalami kendala yang begitu berarti yang dapat 
mempengaruhi hasil ataupun capaian pembelajaran.

Perencanaan pembelajaran di masa pandemi memang tidak cenderung berupa kesiapan administrasi semata, melainkan pada bagaimana merancang pembelajaran sehingga capaian pembelajaran dapat optimal walau di tengah ragam kendala yang dihadapi. Dalam upya itu lah pembelajaran berbasis kontekstual menjadi salah satu pilihan pembelajaran yang paling memungkinkan untuk membuat siswa mencapai perkembangan sebagaimana seharusnya capaian itu diperolah saat tatap muka.

Secara umum jika digambarkan alur perencanaan pembelajaran Al-Qur'an Hadis berbasis kontekstual yang dilaksanakan pada masa pembelajaran daring sebagaimana yang tertera sebagai berikut:
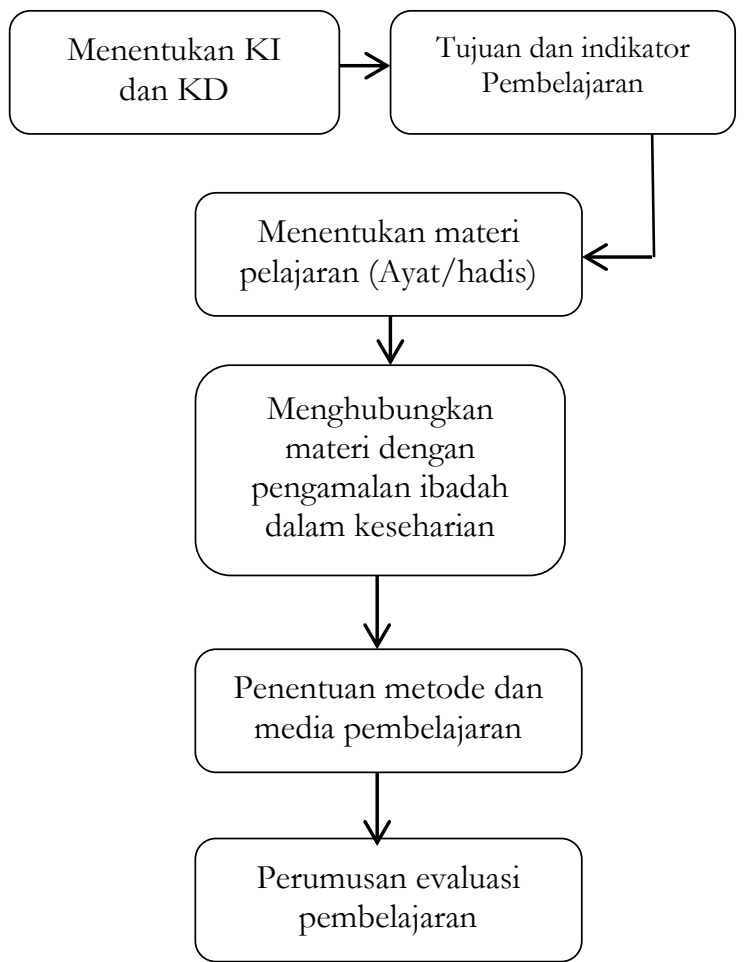

Bagan 2. Alur perencanaan pembelajaran berbasis kontekstual
Pelaksanaan pembelajaran Al-Qur'an

Hadis berbasis kontekstual secara daring

Pembelajaran Al-Qur'an Hadis

berbasis kontekstual dilaksanakan secara dalam jaringan (daring) hal ini sebagaimana aturan yang berlaku dari kementerian pendidikan dan kebudayaan. Pelaksanaan pembelajaran pada dasarnya merealisasikan apa saja yang telah direncanakan dalam proses perencanaan pembelajaran. Materi yang telah ditetapkan kemudian diajarkan kepada siswa, dan yang membedakannya degan strategi pembelajaran lain, strategi pembelajaran kontekstual menghendaki pembiasaan berupa pengamalan terhadap ayat-ayat ataupun hadis yang diajarkan.

Dari observasi yang penulis lakukan terdapat beberapa aktivitas pembelajaran yang melibatkan sikap pembiasaan siswa terjadap materi ayat ataupun Hadis yang diajarkan, seperti membaca tiga surah Qul (Surah Al-Ikhlas, Al-Falaq, dan An-Nas) di awal pembelajaran sebagai bentuk amalan memohon perlindungan kepada Allah Swt, Mengamalkan hadis berkaitan dengan syukur dengan cara membaca kalimat tahmid untuk nikmat yang diterima seperti mendapatkan nilai, mendapatkan pelajaran, mendapatkan nasihat, dan sebagainya. Mengamalkan hadis nabi berkaitan dengan keutamaan dalam menuntut ilmu, yakni dengan cara tekun dalam menuntut ilmu, menghormati guru, menghormati ilmu, dan senantiasa mengerjakan pekerjaan atau tugas yang 
diperintahkan oleh guru.

Hasil wawancara yang penulis lakukan dengan kepala sekolah di MTs. Pendidikan Agama Islam bahwa kepala madrasah tidak memberikan kebijakan khusus terkait dengan model pembelajaran berbasis kontekstual. Sebab dalam kepala madrasah benar-benar mengetahui bagaimana kondisi yang dialami oleh para siswa dan orang tua di masa pandemi Covid-19. Untuk itu pemilihan terhadap aplikasi pembelajaran, metode dan media pembelajaran menjadi hak sepenuhnya guru. Maka tak salah dalam hal ini sangat dituntut kreativitas guru dalam mengemas pembelajaran sehingga hasil yang dicapai tetap optimal.

Seperti apa yang dikatakan oleh Rusman bahwa tidak ada strategi pembelajaran yang paling baik atau yang paling buruk, seluruh strategi pembelajaran baik, jika sesuai dengan karekteristik pembelajaran yang ada, begitu juga sebaliknya tidak akan baik strategi tersebut jika tidak sesuai dengan karekteristik pembelajaran tersebut. Strategi pembelajaran memang bukanah satu-satunya penentu keberhasilan capaian pembelajaran, akan tetapi pembelajaran yang tidak mendesain strategi dalam pembelajarannya pada dasarnya sang guru tersebut tidak menginginkan keberhasilan apapun pada peserta didiknya, dalam arti sekedar sang guru menunaikan kewajibannya semata.

Pembelajaran berbasis kontekstual pada pelajaran Alquran hadits, sebenarnya menuntut kemampuan siswa untuk mengamalkan ayat dan hadits dalam aktivitas ibadah keseharian siswa. dalam arti ayat tidak hanya sekedar untuk dibaca ataupun dihafal melainkan menjadi satu pengamalan dalam kehidupan. Tentunya dalam hal ini peran dampingan orang tua sangatlah diperlukan, sebab tanpa adanya dampingan orang tua siswa sulit untuk memahami kandungan ayat dan hadis yang telah dipaparkan oleh guru pada saat pembelajaran berlangsung. Oleh karena itu dalam pelaksanaan pembelajaran guru juga melakukan kerjasama dengan orang tua, terutama mengawasi aktivitas ibadah siswa dalam keseharian. banyak tokoh pendidikan yang mengatakan bahwa di situasi pandemi Covid 19 waktu belajar anak menjadi lebih banyak dengan orang tua dibanding dengan guru. maka tak salah jika dikatakan keberhasilan pembelajaran daring juga ditentukan oleh keberhasilan orang tua dalam mengarahkan anaknya untuk belajar seoptimal mungkin.

Begitu juga dengan pembelajaran AlQur'an Hadis, amalan-amalan dari keduanya dibiasakan kepada anak-anaknya sehingga terbentuk perilaku sebagaimana yang diharapkan oleh Alquran dan hadis tersebut. banyak penjelasan para ulama yang mengatakan bahwa Alquran dan hadis merupakan sumber dari perilaku atau akhlak dari seseorang, itu artinya seseorang yang 
berperilaku sama saja sedang mengamalkan ayat dan Hadits Rasulullah Saw.

Sebagaimana yang telah disebutkan sebelumnya bahwa pembelajaran dari memang menjadi kendala bagi guru, terutama dalam hal pengawasan ketercapaian perkembangan peserta didik tersebut. maka dalam pembelajaran daring tentu yang menjadi bukti ketercapaian adalah dokumen dokumen berupa video pembelajaran ataupun gambar pembelajaran yang menunjukkan bahwa siswa sedang melakukan amalan-amalan ataupun ibadah sebagaimana tuntutan dari ayat-ayat dan hadis-hadis yang telah disebutkan sebelumnya. Berdasarkan observasi yang peneliti lakukan, Siswa kerap mengirimkan tugas-tugasnya dalam bentuk gambar dan video pembelajaran, seperti mengirimkan tentang hafalan dari surah dan hadis tertentu, Mengirimkan video tentang Ragam contoh perilaku yang menunjukkan sikap yang berasal dari ayat dan hadits tertentu.

\section{Evaluasi pembelajaran Al-Qur'an Hadis berbasis kontekstual secara daring}

Tuntutan kurikulum 2013 dalam hal mengevaluasi hasil pembelajaran siswa diharuskan menggunakan penilaian yang autentik. Penilaian autentik adalah suatu proses pengumpulan, pelaporan dan penggunaan informasi tentang hasil belajar peserta didik dengan prinsip-prinsip penilaian, pelaksanaan berkelanjutan, buktibukti autentik, akurat dan konsisten sebagai akuntabilitas publik. Hal ini sejalan dengan pendapat Johnson yang menyatakan bahwa penilaian autentik memberikan kesempatan luas kepada peserta didik untuk menunjukkan apa yang telah dipelajari dan apa yang telah dikuasai selama proses pembelajaran. Lebih lanjut para ahli menyatakan bahwa penilaian autentik berfokus pada tujuan, melibatkan pembelajaran secara langsung, membangun kerjasama, dan menanamkan tingkat berpikir yang lebih tinggi.

Penilaian terhadap pembelajaran kontekstual dilakukan dengan cara mengobservasi aktivitas ataupun pengamalan ibadah yang dilakukan siswa terhadap ayatayat ataupun hadis-hadis yang telah ditentukan. Penilaian dilakukan dengan mengobservasi bukti pengiriman tugas yang diberikan, baik berupa gambar atau video pembelajaran yang dikirimkan kepada guru. Dalam hal ini guru mengamati gambar-gambar yang menunjukkan aktivitas siswa terkait dengan tuntutan pembelajaran yang diharapkan, begitu juga dengan video pembelajaran yang menunjukkan aktivitas kegiatan siswa. Di samping dengan cara tersebut guru juga melakukan kerjasama dengan orang tua siswa dalam hal mengobservasi kontekstualisasi dari ayat dan Hadis dalam perilaku kehidupan sehari-hari. Hal ini dilakukan dengan cara berdiskusi dalam satu waktu kepada orang tua untuk saling bertanya jawab terkait dengan 
perkembangan anak yang di dirasakan oleh orang tua. Cara seperti ini memang pernah peneliti saksikan, dan dilakukan dengan cara dalam jaringan (daring) menggunakan aplikasi Zoom meeting. Dan ini dilakukan tidaklah setiap hari melainkan dilakukan satu kali dalam semi seminggu. Memang menurut penuturan salah seorang guru mata pelajaran Al-Qur'an Hadis di MTS tersebut, pada awalnya memang terdapat lembar observasi yang diberikan kepada orang tua untuk membantu guru dalam menilai tahapan perkembangan peserta didik. Namun belakangan ini lembar observasi tersebut terkesan diisi asal-asalan atau terdapat juga orang tua yang tidak mau untuk mengisi lembar observasi tersebut. Setelah diwawancarai ternyata ragam alasan yang muncul mulai dari kesibukan ketidaksepahaman ide ataupun juga menganggap bahwa hal itu bukanlah tugas orang tua, melainkan tugas sang guru.

Lembar observasi yang pernah penulis saksikan, berisikan tentang ragam Skala yang telah ditentukan oleh guru seperti sangat baik, baik, cukup, kurang baik, tidak baik. lembar observasi tersebut digunakan untuk menilai ketercapaian pembelajaran siswa dalam bentuk pengamalan, lazimnya guru lazimnya guru akan melakukan wawancara singkat kepada siswa terkait dengan pengamalan pengamalan yang telah dilakukannya, dan memang hal ini Menurut pengamatan peneliti tidaklah akurat, Sebab sangat memungkinkan bagi siswa untuk merekayasa jawaban. Oleh karena itu untuk mengantisipasi hal ini guru tidak hanya mengambil satu sumber penilaian saja akan tetapi mengambil tiga sumber penilaian yakni dari guru, dari orang tua, dan dari siswa itu sendiri.

Penilaian ini tentu akan menjadi dasar pertimbangan bagi guru untuk menentukan ketercapaian hasil pembelajaran. Jika capaian yang pembelajaran sesuai dengan yang diharapkan maka Sang guru lazimnya akan memberikan pengayaan terhadap capaian yang telah didapat oleh siswa, akan Akan tetapi jika capaian pembelajaran tidak sesuai dengan yang diharapkan maka lazimnya guru akan melakukan remedial, Bahkan melakukan komunikasi yang Intens dengan orang tua, dan Dalam kondisi ini sangat memungkinkan bagi guru untuk bertemu langsung dengan orangtua untuk melakukan kan Perlakuan khusus untuk perbaikan sikap ataupun keterampilan siswa.

Pembelajaran kontekstual tidak dinilai dari sejauh mana siswa Mampu membaca ayat dan hadis ataupun memahami kandungan ayat dan hadis. akan tetapi dinilai dari sejauh mana siswa mampu untuk mengamalkan ayat dan Hadis dalam perilaku kehidupan sehari-hari. Kemampuan siswa mengamalkan ayat dan hadis dalam kehidupannya tersebut menjadi satu bukti bahwa siswa telah mampu mengkonstruksi 
pemahaman yang ia miliki dengan perilakunya dalam kehidupan sehari-hari. Kemampuan siswa mengkonstruksi pemahaman tersebutlah yang disebut dalam Puncak pembelajaran kontekstual.

\section{SIMPULAN}

Berdasarkan pembahasan yang telah dikemukakan di atas maka dapatlah ditarik simpulan penelitian, yakni perencanaan pembelajaran Al-Qur'an Hadis berbasis kontekstual secara daring dilakukan dengan menetapkan kompetensi inti dan kompetensi dasar, keduanya sebagai dasar dalam merumuskan tujuan dan indikator pembelajaran. Materi pelajaran yang dikemukakan disesuaikan dengan pengalaman yang sengaja direncanakan untuk dilakukan oleh siswa. Pelaksanaan pembelajaran dilakukan secara daring, dengan langkah menyampaikan materi pelajaran, lalu kemudian manyampaikan kepada siswa ragam pengalaman yang harus mereka lakukan di rumah dengan didampingi orang tua. Pelaksanaan yang dilakukan dirumah tersebut kemudian di evaluasi dengan cara observasi atau pengamatan sikap dan keterampilan yang dilakukan oleh siswa. Pengamatan dilakukan dengan dua sudut, yakni guru sebagai observer dan orang tua juga sebagai observer tambahan.

\section{DAFTAR PUSTAKA}

Abrianto, D., Setiawan, H. R., \& Fuadi, A. (2018). Implementasi Kurikulum 2013
Pada Mata Pelajaran Alquran Hadits di MTs. Swasta Teladan Gebang Kab. Langkat. Intiqad: Jurnal Agama Dan Pendidikan Islam, 10(2), 283-298.

Al-Balushi, S. M., Ambusaidi, A. K., AlBalushi, K. A., Al-Hajri, F. H., \& AlSinani, M. S. (2020). Student-Centred and Teacher-Centred Science Classrooms as Visualized by Science Teachers and their Supervisors. Teaching and Teacher Education, 89(3), 103014. https://doi.org/https://doi.org/10.101 6/j.tate.2019.103014

Budianto, E. (2010). Pendidikan Karakter Melalui Pembelajaran PAI Berbasis Kontekstual. Progresiva, 4(1), 161822. https://ejournal.umm.ac.id/index.php/ progresiva/article/view/2043

Juliana, R. (2014). Pengarub Strategi Pembelajaran Contextual Teaching and Learning (CTL) dan Pemanfaatan Sumber Belajar terhadap Hasil Belajar Siswa dalam bidang Studi Al-Quran Hadis di MAN 1 Padangsidimpuan Padangsidimpuan]. http://etd.iainpadangsidimpuan.ac.id/3413/

Kusen, K. (2017). Peningkatan Mutu Pendidikan Agama Islam Berbasis Kontekstual. Tadbir: Jurnal Studi Manajemen Pendidikan, 1(2), 189-214. http://dx.doi.org/10.29240/jsmp.v1i2. 300

Lubis, M., Yusri, D., \& Gusman, M. (2020). Pembelajaran Pendidikan Agama Islam Berbasis E-Learning (Studi Inovasi Pendidik MTS. PAI Medan di Tengah Wabah Covid-19). Fitrab: Journal of Islamic Education, 1(1), 1-15. http://jurnal.staisumateramedan.ac.id/index.php/fitrah/article/vi ew/1

Lubis, R. R., Hanafiah, M. A., Sartika, D., Hasibuan, A. A., \& Nawawi, K. H. (2019). Taḥīz Online: (Studi Menghafal Al-Quran Pada Masa Pandemi Covid-19 di MIS Ubudiyah Medan). Jurnal Pendidikan Islam, 9(2), 60-75. 
https://doi.org/10.38073/jpi.v9i2.253

Lubis, R. R., Mahrani, N., Margolang, D., \& Assingkily, M. S. (2020). Pembelajaran Al-Qur'an Era Covid-19: Tinjauan Metode dan Tujuannya pada Masyarakat di Kutacane Aceh Tenggara. Kuttab, 4(2).

Muhayanti, S., \& Yulia, L. D. (2020). Penerapan Pembelajaran Kontekstual untuk Meningkatkan Prestasi Belajar Siswa pada Mata Pelajaran Al-Qur'an Hadis Kelas V Di Mi Al-Karomah Talang Ogan. JPGMI Jurnal Pendidikan Guru Madrasah Ibtidaiyah Al-Multazam), 6(1), 1-15. https://www.ojs.stitmultazam.ac.id/ind ex.php/JPGMI/article/view/67

Muthmainnah, M., \& Herawati, H. (2021). Pembelajaran PAI berbasis adab kontekstual. Pionir: jurnal pendidikan, 10(1).

http://dx.doi.org/10.22373/pjp.v10i1.9 749

Nafia, A. I. (2017). Pengelolaan Pembelajaran Kontekstual Pendidikan Agama Islam. Inspirasi: Jurnal Kajian Dan Penelitian Pendidikan Islam, 1(1), 51-70.

Nasution, M. H. (2019). Pelaksanaan Strategi Pembelajaran Kontekstual Al-Quran Hadist di Madrasah Tsanawiyah Swasta AlWashliyah Medan Krio Kecamatan Sunggal Universitas Islam Negeri Sumatera Utara Medan]. http://repository.uinsu.ac.id/10413/

Ni'mah, N. L. (2017). Rekontruksi Manajemen pembelajaran Al-Quran Hadist di Madrasah Aliyah Al-Ma'arif Singosari Malang. Program Pascasarjana Pendidikan Islam Universitas Islam Malang.

Safitri, M. (2016). Pengaruh Pengelolaan Pembelajaran dan Penggunaan Model Pembelajaran Kontekstual terhadap Kinerja Guru. Conciencia, 16(1), 107122.

https://doi.org/10.19109/conciencia.v $16 \mathrm{i} 1.3415$
Sista, T. R. (2017). Implementasi Manajemen Kurikulum dalam Meningkatkan Mutu Pendidikan. Educan: Jurnal Pendidikan Islam.

https://doi.org/10.21111/educan.v1i1. 1288

Syahdan, S. (2019). Peningkatan Motivasi dan Ketuntasan Belajar melalui Penerapan Pembelajaran Kontekstual Berbasis Pemodelan. NUSANTARA, 1(3), 317338.

Waseso, H. (2018). Kurikulum 2013 Dalam Prespektif Teori Pembelajaran Konstruktivis. Ta'lim: Jurnal Studi Pendidikan Islam, 1(1), 20-35. http://ejurnal.unisda.ac.id/index.php/talim/arti cle/view/632

Winata, K. A., Solihin, I., Ruswandi, U., \& Erihadiana, M. (2020). Moderasi Islam dalam Pembelajaran PAI Melalui Model Pembelajaran Kontekstual. Ciencias: Jurnal Penelitian Dan Pengembangan Pendidikan, 3(2), 82-92. https://ejournal.upg45ntt.ac.id/ciencias /article/view/61

Wirdati, W., \& Sulaiman, S. (2018). AZASAZAS Pembelajaran Kontekstual dalam Perspektif Islam. Ta'dib, 21(1), 29-38. http://dx.doi.org/10.31958/jt.v21i1.10 39

Zakariah, M., Khan, M. K., Tayan, O., \& Salah, K. (2017). Digital Quran computing: review, classification, and trend analysis. Arabian Journal for Science and Engineering, 42(8), 3077-3102. https://doi.org/10.1007/s13369-0172415-4

Zaman, B. (2020). Aplikasi Pendekatan Kontekstual pada Proses Pembelajaran Rumpun Pendidikan Agama Islam. Profetika: Jurnal Studi Islam, 20(2), 133142.

https://doi.org/10.23917/profetika.v20 i2. 9950 